\title{
Acid-sensing ion channel 3 decreases phosphorylation of extracellular signal-regulated kinases and induces synoviocyte cell death by increasing intracellular calcium
}

\author{
Weiyi Gong ${ }^{1,2}$, Sandra J Kolker ${ }^{2}$, Yuriy Usachev ${ }^{3}$, Roxanne Y Walder ${ }^{2}$, David L Boyle ${ }^{4}$, Gary S Firestein ${ }^{4}$
} and Kathleen A Sluka ${ }^{*}$

\begin{abstract}
Introduction: Acid-sensing ion channel 3 (ASIC3) is expressed in synoviocytes, activated by decreases in pH, and reduces inflammation in animal models of inflammatory arthritis. The purpose of the current study was to characterize potential mechanisms underlying the control of inflammation by ASIC3 in fibroblast-like synoviocytes (FLS).

Methods: Experiments were performed in cultured FLS from wild-type (WT) and ASIC3-/- mice, ASIC1-/- mice, and people with rheumatoid arthritis. We assessed the effects of acidic pH with and without interleukin-1 $\beta$ on FLS and the role of ASICs in modulating intracellular calcium $\left[\mathrm{Ca}^{2+}\right]_{\text {i, }}$ mitogen activated kinase (MAP kinase) expression, and cell death. $\left[\mathrm{Ca}^{2+}\right]_{i}$ was assessed by fluorescent calcium imaging, MAP kinases were measured by Western Blots; ASIC, cytokine and protease mRNA expression were measured by quantitative PCR and cell death was measured with a LIVE/DEAD assay.
\end{abstract}

Results: Acidic $\mathrm{pH}$ increased $\left[\mathrm{Ca}^{2+}\right]_{i}$ and decreased p-ERK expression in WT FLS; these effects were significantly smaller in ASIC3-/- FLS and were prevented by blockade of $\left[\mathrm{Ca}^{2+}\right]_{\text {. }}$. Blockade of protein phosphatase 2A (PP2A) prevented the pH-induced decreases in p-ERK. In WT FLS, IL-1 $\beta$ increases ASIC3 mRNA, and when combined with acidic pH enhances $\left[\mathrm{Ca}^{2+}\right]_{i}, \mathrm{p}$-ERK, IL-6 and metalloprotienase mRNA, and cell death. Inhibitors of $\left[\mathrm{Ca}^{2+}\right]_{i}$ and ERK prevented cell death induced by pH 6.0 in combination with IL-1 $\beta$ in WT FLS.

Conclusions: Decreased $\mathrm{pH}$ activates ASIC3 resulting in increased $\left[\mathrm{Ca}^{2+}\right]_{\mathrm{i}}$, and decreased p-ERK. Under inflammatory conditions, acidic pH results in enhanced $\left[\mathrm{Ca}^{2+}\right]_{i}$ and phosphorylation of extracellular signal-regulated kinase that leads to cell death. Thus, activation of ASIC3 on FLS by acidic pH from an inflamed joint could limit synovial proliferation resulting in reduced accumulation of inflammatory mediators and subsequent joint damage.

\section{Introduction}

Acid-sensing ion channels (ASICs) are the primary acid sensors in nociceptors, and substantial work shows that activation of acid sensing ion channels (ASIC1, ASIC3) contributes to the development of musculoskeletal pain [1-8]. However, we previously demonstrated localization of ASIC3 protein to Type B synoviocytes in mouse joint, and ASIC3 protein and mRNA in cultured fibroblast-

\footnotetext{
* Correspondence: kathleen-sluka@uiowa.edu

${ }^{2}$ Department of Physical Therapy and Rehabilitation Science, Pain Research Program, University of lowa Carver College of Medicine, 500 Newton Road, 1-248 Medical Education Building, lowa City, IA 52242, USA

Full list of author information is available at the end of the article
}

like synoviocytes (FLS) [6,9]. Acidic pH in cultured FLS increases $\left(\mathrm{Ca}^{2+}\right)_{\mathrm{i}}$, and facilitates release of hyaluronic acid; these $\mathrm{pH}$-dependent effects are reduced in FLS from ASIC3-/- mice [9].

Rheumatoid arthritis (RA) is a systemic inflammatory disease that particularly affects synovial joints. Acidic $\mathrm{pH}$ is associated with inflammation in rheumatoid joints where $\mathrm{pH}$ drops between $\mathrm{pH} 6.0$ and 7.0 [10,11]. ASIC3 senses decreases in $\mathrm{pH}$ within the physiological range that would normally be found within an inflamed joint $(\mathrm{pH} 6.0$ to 7.0$)[5,12]$. In RA, synoviocytes are key players in the production of inflammatory mediators and proteases that 
subsequently enhance the inflammatory process and joint damage [13-17]. Surprisingly, we found that ASIC3-/mice have enhanced inflammation, despite reduced pain behaviors, in the collagen-induced arthritis model [1]. The enhanced inflammation is accompanied by increased joint destruction and inflammatory mediator production [1]. As inflammatory mediators and decreases in $\mathrm{pH}$ occur simultaneously in inflammatory arthritis, we further tested the effects of combining acidic $\mathrm{pH}$ with IL- $1 \beta$ - this combination results in cell death [1]. Thus, ASIC3 appears to play a protective role in joints. Although ASIC1 is expressed in FLS, the role of ASIC1 in FLS is unclear.

Increases in $\left(\mathrm{Ca}^{2+}\right)_{\mathrm{i}}$ have multiple effects on cells including modulation of intracellular messengers and promotion of cell death. The intracellular signaling molecules mitogen-activated protein kinases (MAPKs) in FLS are critical players in the inflammatory process in RA. MAPKs are activated by cytokines and Toll-like receptors in human FLS with a subsequent positive feedback loop that enhances expression of inflammatory cytokines [16-20]. For example, the MAPK c-Jun N-terminal kinase (JNK) increases MMP3 gene expression to increase cellular matrix degradation, which results in joint destruction [18,20-22]. JNK2-/- mice have modestly lower cartilage destruction, and inhibition with a non-specific JNK antagonist reduces expression and release of inflammatory cytokines [19,22]. MAPK activation, including extracellular signal-regulated kinase (ERK), JNK, and p38, can result in cell death in a variety of cell types including neurons, cancer, chondrocytes, and macrophages [23-26]. Interestingly, increased $\left(\mathrm{Ca}^{2+}\right)_{\mathrm{i}}$ enhances PP2A catalytic subunit expression which results in decreased ERK phosphorylation [27]. It is, therefore, possible that low pH activates ASIC3 to increase $(\mathrm{Ca} 2+)_{i}$, which in turn reduces MAPK activation and promotes cell death. The purpose of the current study was to characterize potential mechanisms underlying the control of inflammation by ASIC3 in FLS, compared to wild-type (WT) and ASIC1 FLS. Specifically we tested if (1) ASIC1 and ASIC3 mediate acidic pH-induced increases in $(\mathrm{Ca} 2+)_{\mathrm{i}}$ in FLS; (2) acidic $\mathrm{pH}$ changes phosphorylation and expression of MAPK through ASIC1 and ASIC3; (3) effects of $\mathrm{pH}$ on $(\mathrm{Ca} 2+)_{\mathrm{i}}$ and MAPK are enhanced in the presence of the inflammatory cytokine IL-1 $\beta$, and (4) increases in $(\mathrm{Ca} 2+)_{i}$ drive the changes in MAPK activity and cell death.

\section{Methods}

Mice

C57Bl/6 J mice (WT), and congenic ASIC3-/- and AISC1-/- mice on a C57B1/6 J background were bred at the University of Iowa or the University of California San Diego Animal Care Facility. The ASIC3-/- and ASIC1-/mice strains have been previously described and characterized in multiple studies $[7,8,28,29]$. Male mice, 9 to
10 weeks of age, were used in these studies. All experiments using animals were approved by Animal Care and Use Committee at the University of Iowa and the University of California San Diego, and conducted in accordance with National Institutes of Health (NIH) guidelines. Use of synoviocytes from human subjects was approved by the Institutional Review Board in the Human Subjects Office at the University of Iowa and in the Human Subjects Protection Program at the University of California San Diego.

\section{Fibroblast-like synoviocyte (FLS) isolation and culture Preparation of FLS from mice}

FLS were isolated from WT, ASIC3-/- and ASIC1-/- mice according to previously published methods $[14,19]$. Mice were euthanized with sodium pentobarbital $(100 \mathrm{mg} / \mathrm{kg}$, ip) and the limbs excised above the knee and elbow joints. After rinsing the excised limbs in ethanol, the knee, ankle and elbow joints were stripped of muscle and tendon. The remaining bone and tissue were finely minced and incubated in $0.5 \mathrm{mg} / \mathrm{ml}$ Type VIII collagenase (Sigma, St. Louis, MO, USA) in RPMI (Invitrogen, Carlsbad, CA, USA) at $37^{\circ} \mathrm{C}$ for $2 \mathrm{~h}$. The tissue was pelleted at $1,200 \mathrm{rpm}$ and the supernatant discarded. The pellet was rinsed twice in high-glucose DMEM (Gibco, Invitrogen, Carlsbad, CA, USA) supplemented with penicillin, streptomycin, $10 \%$ FBS, and $0.5 \%$ gentamycin (Cellgro, Manassas, VA, USA), resuspended, plated onto T75 culture flasks and incubated at $37^{\circ} \mathrm{C}$ with $5 \% \mathrm{CO}_{2}$. FLS were grown until $>80$ to $90 \%$ confluent before passaging. FLS were at passage 3 to 4 for use in western blot, $(\mathrm{Ca} 2+)_{\mathrm{i}}$, mRNA expression studies, and Live/Dead assays.

\section{Preparation of human synovial tissue and FLS}

This study was approved by the Institutional Review Board of University of California, San Diego School of Medicine and informed consent was obtained from all participants. Synovial tissue was obtained from patients with RA at the time of total joint replacement or synovectomy as previously described. The diagnosis of RA conformed to American College of Rheumatology 1987 revised criteria. The samples were processed for cell culture. The synovium was minced and incubated with $1 \mathrm{mg} / \mathrm{ml}$ collagenase type VIII (Sigma) in serum-free RPMI 1640 (Gibco BRL, Grand Island, NY, USA) for $1 \mathrm{~h}$ at $37^{\circ} \mathrm{C}$, filtered, extensively washed, and cultured in DMEM (Gibco BRL) supplemented with 10\% FBS (Gemini Bio Products, Calabasas, CA, USA), penicillin, streptomycin, gentamicin, and glutamine, in a humidified $5 \% \mathrm{CO}_{2}$ atmosphere. Cells were allowed to adhere overnight, non-adherent cells were removed, and adherent FLS were split at $1: 3$ when 70 to $80 \%$ confluent. FLS were used from passage 3 through 9 during which time they are a homogeneous population of cells ( $<1 \%$ CD11b-positive, $<1 \%$ phagocytic, and $<1 \%$ Fc $\gamma$ RIIand FcyRIII-receptor-positive). FLS were cultured and 
used at $80 \%$ confluence. Cells were synchronized in $0.1 \% \mathrm{FBS}$ for $24 \mathrm{~h}$ before the addition of the appropriate stimulus.

\section{Calcium imaging}

External physiological $\mathrm{pH}$ solutions used for $\mathrm{Ca}^{2+}$ imaging contained $120 \mathrm{mM} \mathrm{NaCl}, 5 \mathrm{mM} \mathrm{KCl}, 1 \mathrm{mM} \mathrm{MgCl}$, $2 \mathrm{mM} \mathrm{CaCl}_{2}, 10 \mathrm{mM}$ HEPES, and $10 \mathrm{mM}$ MES; the $\mathrm{pH}$ of each solution was adjusted with tetramethylammonium hydroxide, and osmolarity was adjusted with tetramethylammonium chloride [30]. Cells were plated at 30,000 cells/dish in poly-L-lysine (Sigma) coated 35-mm glass-bottom petri dishes (MatTek Corp., Ashland, MA, USA), and grown for $24 \mathrm{~h}$ in $10 \% \mathrm{FBS}$, antibioticsupplemented DMEM and subsequently serum-starved (0.1\% FBS, antibiotic-supplemented DMEM) $24 \mathrm{~h}$ prior to testing.

After rinsing with $\mathrm{pH} 7.4$ external buffer, cells were loaded with the $\mathrm{Ca}^{2+}$-sensitive fluorescent indicator Oregon Green BAPTA-1 AM (OGB-1) (Invitrogen, $8 \mu \mathrm{g} / \mathrm{ml}$ (made from a $2.5 \mu \mathrm{g} / \mu \mathrm{l}$ DMSO stock), containing 0.013\% pluronic F-127, (Invitrogen, diluted from a 20\% DMSO stock) in $\mathrm{pH} 7.4,1 \mathrm{~h}$, room temperature) as we previously described [9]: $10 \mathrm{ml}$ of $\mathrm{pH}$ and treatment solutions were introduced into the culture dish at a rate of $100 \mu \mathrm{l} / \mathrm{s}$ through a syringe pump (Harvard Apparatus PHD2000, Holliston, MA). Solution was simultaneously removed from the opposite side of the dish by vacuum aspiration.

Fluorescence was measured on a 150-s time course before, during, and after application of $\mathrm{pH}$ solutions. An Olympus IX81 motorized inverted microscope and integrated Intelligent Imaging Innovation's Slidebook software, v.4.1 was used to capture images. Analysis was done using Image J (NIH) to measure the change of intensity in a constant, defined area of the cell during each $\mathrm{pH}$ application. Each session started with $\mathrm{pH} 7.4$ infusion for $20 \mathrm{~s}$, followed by 2 minutes of acidic $\mathrm{pH}$. Between $\mathrm{pH}$ solutions, $\mathrm{pH} 7.4$ was again infused. All $\mathrm{pH}$ solutions were applied in increasing acidic $\mathrm{pH}$ to each culture dish with $\mathrm{pH} 7.4$ infused between each solution. Percent change in $(\mathrm{Ca} 2+)_{i}$ was quantified using the formula:

$$
\% \Delta_{\mathrm{F}}=\left(\mathrm{F}-\mathrm{F}_{0}\right) / \mathrm{F}_{0} * 100,
$$

where $\mathrm{F}$ is the fluorescence intensity at any given time point and $\mathrm{F}_{0}$ is fluorescence intensity under control conditions ( $\mathrm{pH}=7.4$, calculated by averaging the intensities recording during the first 20 s of each time course). The area under the curve during the 2-minute time period was calculated using the percent-change scores; zero represented no change in area and a positive number represented an increase in calcium intensity.
For $\mathrm{Ca}^{2+}$-free $\mathrm{pH}$ solutions calcium chloride was eliminated from the external buffers and $\mathrm{NaCl}$ adjusted osmolarity to $123 \mathrm{mM}$. For $(\mathrm{Ca} 2+)_{\mathrm{i}}$ blockade, $30 \mu \mathrm{M}$ cyclopiazonic acid (CPA, Sigma-Aldrich) was added to the cultures after OGB-1 loading, 5 minutes prior to $\mathrm{Ca}^{2+}$ imaging $(12 \mu \mathrm{M}$ CPA was included in treatment during $\mathrm{Ca}^{2+}$ imaging). In the IL- $1 \beta$ study, $1 \mathrm{ng} / \mathrm{ml} \mathrm{IL-1} \beta$ ( $\mathrm{R}$ and D Systems, Minneapolis, MN, USA) was included in $0.5 \%$ FBS serum-starved media $24 \mathrm{~h}$ prior to $\mathrm{Ca}^{2+}$ imaging.

Two cell culture lines were used for testing FLS from the WT, ASIC3-/- and ASIC1-/-, $\mathrm{Ca}^{2+}$ source study, and the IL-1 $\beta$ study. Two cell cultures lines from control (for example, WT) and experimental groups (for example, ASIC1-/-) were always run on the same day to control for differences due to loading or imaging. The profiles of percent change $(\% \Delta)$ as a function of time for all viable cells in a group were averaged and compared, taken as a percent change from the WT average at $\mathrm{pH} 5$ or compared to maximum intensity for each cell.

Amiloride (100, 250, $500 \mu \mathrm{M}$; Sigma) was added to cultured human FLS, after OGB-1 loading, 10 minutes prior to and during calcium imaging. Percent change in $(\mathrm{Ca} 2+)_{\mathrm{i}}$ was quantified using the formula:

$$
\% \Delta_{\mathrm{F}}=\left(\mathrm{F}-\mathrm{F}_{0}\right) / \mathrm{F}_{0} * 100,
$$

where $\mathrm{F}$ is the fluorescence intensity at any given time point and $F_{0}$ is fluorescence intensity under control conditions. Three cell culture lines were used for RA FLS study under each condition.

\section{Quantitative real-time polymerase chain reaction (qPCR)}

FLS were plated at 100,000 cells/well in a 6-well tissue culture plate and grown for $24 \mathrm{~h}$ in $10 \% \mathrm{FBS} / \mathrm{DMEM}$ at $37^{\circ} \mathrm{C}$ with $5 \% \mathrm{CO}_{2}$ and subsequently incubated in $0.5 \% \mathrm{FBS} /$ DMEM for $24 \mathrm{~h}$ with or without $2 \mathrm{ng} / \mathrm{ml} \mathrm{IL-1 \beta}$ (Calbiochem, San Diego, CA, USA). FLS were then incubated in $0.5 \%$ FBS/DMEM pH 7.4 or pH 6.0 for $24 \mathrm{~h}$. Cells were then lysed in RNA STAT-60 (Tel-Test, Friendswood, TX, USA). FLS RNA isolation and qPCR was performed as previously described [31]. Using cDNA, mRNA expression of IL-6, metalloproteinases (MMPs) and ASICs was measured by TaqMan Gene Expression Assay (Applied Biosystems). The threshold cycle $(\mathrm{Ct})$ values were used to calculate the number of cell equivalents using a standard complementary DNA curve as previously described [31]. The data were normalized to the expression of HPRT (hypoxanthine guanine phosphoribosyltransferase) and the results were expressed as relative expression units. We examined mRNA expression for IL-6, MMP-3 and MMP-13 from WT and ASIC3-/- FLS with and without treatment with IL-1 $\beta$ ( $\mathrm{n}=3$ preparations/group), and for ASIC3 and ASIC1 in WT FLS with and without IL$1 \beta$ at $\mathrm{pH}$ 7.4 $(\mathrm{n}=4$ preparations/group). Different cell 
culture lines were used for each group (for example, WT, ASIC3-/-).

\section{Western blot analysis}

FLS were plated in six-well plates at 200,000 cells/well, and grown $24 \mathrm{~h}$ and then incubated in 0.1\% FBS/DMEM for $24 \mathrm{~h}$ before addition of stimulating factors. Western blot analysis was performed as described previously [5]. After treatments (see below), protein was extracted with lysis buffer $(50 \mathrm{mM}$ HEPES, $150 \mathrm{mM} \mathrm{NaCl}, 25 \mathrm{mM}$ $\mathrm{MgCl}_{2}, 1 \mathrm{mM}$ EDTA, 10\% Glycerol, 1\% tritonX-100, $20 \mathrm{mM} \beta$-glycerophosphate, $10 \mathrm{mM} \mathrm{NaF}, 1 \mathrm{mM} \mathrm{Na}_{3} \mathrm{VO}_{4}$, supplemented with Complete Proteinase inhibitors (Roche Applied Science, Indianapolis, IN, USA)) and protein concentration determined using the Micro BCA Protein Assay Kit (Thermo Scientific, Rockford, IL, USA). Samples containing $25 \mu \mathrm{g}$ of protein were resolved on Invitrogen NuPAGE $4 \%$ to $12 \%$ Bis Tris gels and transferred to a polyvinylidene fluoride (PVDF) membrane. The membranes were blocked with $5 \%$ non-fat milk, incubated with primary Ab (all from Cell Signaling Technology, Boston, MA, USA) at $4^{\circ} \mathrm{C}$ overnight, followed by horseradish peroxidase-conjugated secondary $A b$ for $1 \mathrm{~h}$. Membranes were developed and imaged using the UVP Bioimaging systems and density of the band was quantified using Image J software (NIH). $\beta$-actin was used as a loading control and used as an internal control, and all blots were normalized to $\beta$-actin. Data were normalized to the response at $\mathrm{pH}$ 7.4. All western blot data analyzed included controls and experimental data for each condition. Data are expressed as the ratio compared to the control. Each blot contained three replicates of control and three replicates of experimental conditions. Each control and experimental condition was run in three separate primary cell cultures for a total of nine preparations for each condition ( $n=9 /$ condition).

\section{Live/Dead assays}

FLS were plated onto $12 \mathrm{~mm}$ poly-L-lysine-coated round coverslips in 24-well tissue culture plates at 15,000 cells/ well and incubated for $24 \mathrm{~h}$ in DMEM complete medium at $37^{\circ} \mathrm{C}$ in an atmosphere of $5 \% \mathrm{CO}_{2}$. FLS were then incubated for $24 \mathrm{~h}$ in $0.5 \%$ FBS/DMEM serum starved medium IL- $1 \beta, 1 \mathrm{ng} / \mathrm{ml}$.

To determine $\mathrm{Ca}^{2+}$ dependency for cell death, FLS were treated $1 \mathrm{~h}$ at $37^{\circ} \mathrm{C}$ in $0.5 \% \mathrm{FBS} / \mathrm{DMEM}$ with or without BAPTA-AM $(1 \mu \mathrm{M}, \mathrm{pH} 7.4)$, and then treated for $24 \mathrm{~h}$ in $0.5 \% \mathrm{FBS} / \mathrm{DMEM}$ of $\mathrm{pH} 7.4$ or $\mathrm{pH}$ 6.0. To determine if $\mathrm{p}$ ERK contributes to the cell death, FLS were treated $1 \mathrm{~h}$ with PD98059 $(10 \mu \mathrm{M}, \mathrm{pH} 7.4)$ and then $24 \mathrm{~h}$ in $0.5 \%$ FBS/DMEM of pH 6.0 with PD98059 $(10 \mu \mathrm{M})$.

Live/Dead assays (Invitrogen) were performed as described previously [1] using a Live/Dead Viability/Cytotoxicity kit (L-3224; Invitrogen), $0.5 \mathrm{mM}$ calcein AM, and $0.5 \mathrm{mM}$ ethidium homodimer 1 . Stained cells were then mounted on slides with aqueous CMF-1 mounting medium (Electron Microscopy Sciences, Hatfield, PA)) and imaged with an Olympus BX51 fluorescence microscope with a spot camera. Image J software $(\mathrm{NIH})$ was used to merge and quantify live and dead cells. Data are expressed as the percentage of dead cells. Each experimental condition was analyzed in three different primary cell cultures. An average number of $713 \pm 28$ cells were counted for each primary cell culture in each condition.

\section{Statistical analysis}

Data are expressed as mean \pm standard error of the mean (SEM). $(\mathrm{Ca} 2+)_{\mathrm{i}}$ in response to different $\mathrm{pH}$ in FLS from WT, ASIC1-/ and ASIC3-/- FLS were analyzed by repeated-measures analysis of variance (ANOVA) followed by Tukey's post hoc test for differences between groups. Differences in $\mathrm{Ca}^{2+}$ imaging, western Blots, $\mathrm{qPCR}$, and Live-Dead assays for individual experiments were analyzed with one-way ANOVA followed by Tukey's post-hoc test for group differences. $P$-values less than 0.05 were considered significant.

\section{Results}

\section{Acidic $\mathrm{pH}$ increases $(\mathrm{Ca} 2+)_{\mathrm{i}}$ in $\mathrm{FLS}$}

To determine if decreases in $\mathrm{pH}$ activate FLS, we performed a $\mathrm{pH}$-response curve from WT FLS $(\mathrm{n}=258$ cells). Figure $1 \mathrm{~A}$ and $\mathrm{B}$ shows the traces of all cells averaged across time from WT FLS normalized to $\mathrm{pH}$ 7.4. When compared to responses at $\mathrm{pH} 7.4, \mathrm{pH} 5.0$ produced the maximal increases in $(\mathrm{Ca} 2+)_{\mathrm{i}}(944 \pm 53$ arbitrary units). Increases in $(\mathrm{Ca} 2+)_{i}$ at increasing $\mathrm{pH}$ were progressively smaller, with $\mathrm{pH} 5.5$ showing near peak response $(938 \pm 64), \mathrm{pH} 6.0$ showing a moderate response $(420 \pm 57)$, and $\mathrm{pH} 6.8$ showing minimal responses $(82 \pm$ 23) (Figure 1C).

\section{ASIC1 and ASIC3 contribute to acidic $\mathrm{pH}$-induced $(\mathrm{Ca} 2+)_{\mathrm{i}}$ increase}

To determine the contribution of ASIC3-/- and ASIC1-/to the increases in $(\mathrm{Ca} 2+)_{\mathrm{i}}$, we performed a $\mathrm{pH}$-dose response curve in FLS from ASIC3- $/-(\mathrm{n}=103$ cells $)$ and ASIC1-/ $(\mathrm{n}=198$ cells $)$ mice. Figure $1 \mathrm{~A}$ and $\mathrm{B}$ shows the traces of all cells averaged across time from ASIC3-/- and ASIC1-/- FLS in comparison to WT FLS analyzed under the same conditions. As individual cells show a variation in intensity, the response from knockouts was normalized to peak response observed in WT FLS at pH 5.0. As shown in Figure $1 \mathrm{C}$ there was a significant reduction in $(\mathrm{Ca} 2+)_{\mathrm{i}}$ intensity at all $\mathrm{pH}$ 's tested in both $\mathrm{ASIC} 3-/-$ and ASIC1-/- FLS.

The contribution of intracellular or extracellular $\mathrm{Ca}^{2+}$ to the increases in $(\mathrm{Ca} 2+)_{\mathrm{i}}$ produced by decreases in $\mathrm{pH}$ was then examined by evaluating decreasing $\mathrm{pH}$ in WT 

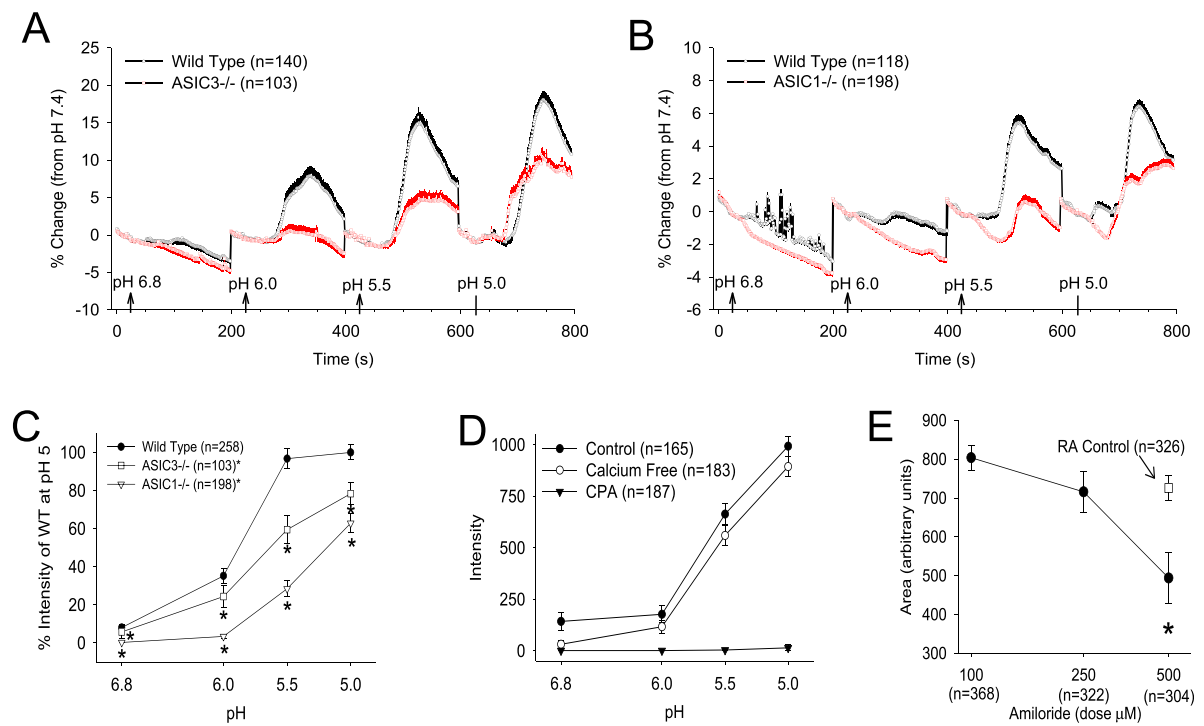

Figure $1 \mathrm{Ca}^{2+}$ imaging determines the responses of $(\mathrm{Ca} 2+)_{i}$ to acidic $\mathrm{pH}$ in fibroblast-like synoviocytes (FLS). (Ca2+); intensity was calculated for each pH over a 150-s application and normalized as a percent change to the response to $\mathrm{pH}$ 7.4. (A) (Ca2+), intensity normalized to $\mathrm{pH} 7.4$ for decreasing pH concentrations in wild-type (WT) and acid-sensing ion channel (AS/C3-/) FLS. Notice a progressive increase in (Ca2+) intensity with decreasing doses of $\mathrm{pH}$. (Ca2+), intensity from ASIC3 $-/$ - run simultaneously showed reduced $(\mathrm{Ca} 2+)_{\mathrm{i}}$ intensity with acidic pH. (B) $(\mathrm{Ca} 2+)_{\mathrm{i}}$ intensity normalized to $\mathrm{pH} 7.4$ for decreasing $\mathrm{pH}$ concentrations in WT and ASIC1- - FLS. (Ca2+)i intensity from ASIC1- - FLS run simultaneously showed reduced (Ca2+) intensity with acidic $\mathrm{pH}$. (C) Data for ASIC3-/- and ASIC1-/- were normalized to the (Ca2+) $)_{i}$ of WT cells at pH 5.0 to control for variability between cells and between days. A dose-dependent increase in (Ca2+) $)_{\mathrm{i}}$ occurred in both WT, ASIC3 $\%$ - and ASIC1-\% FLS. However, when compared to WT FLS, ASIC3-/- and ASIC1-1- FLS showed significantly reduced (Ca2+) at all pH's tested when compared to WT FLS ( $\left.{ }^{*}><0.05\right)$. (D) In WT FLS, replacement of the extracellular bath with a $\mathrm{Ca}^{2+}$-free medium had no effect on the increases in $(\mathrm{Ca} 2+)_{i}$ to acidic-pH. Blockade of (Ca2+); stores with cyclopiazonic acid (CPA) $(30 \mu \mathrm{M})$ completely abolished the $(\mathrm{Ca} 2+)_{\mathrm{i}}$ increases produced by acidic pH $\left({ }^{*} P<0.05\right)$. (E) $(\mathrm{Ca} 2+)_{\mathrm{i}}$ in FLS from people with rheumatoid arthritis show an increase in response to $\mathrm{pH} 6.0$ when compared to responses at $\mathrm{pH} 7.4$ (RA control). This increase in (Ca2+) iresponse to pH 6.0 is significantly reduced by the non-specific ASIC blocker amiloride $(500 \mu \mathrm{M})(P<0.05)$.

FLS in a $\mathrm{Ca}^{2+}$-free medium ( $\mathrm{n}=183$ cells) or after depletion of $\mathrm{Ca}^{2+}$ stores with the sarco-endoplasmic reticulum $\mathrm{Ca}^{2+}$-ATPase (SERCA) inhibitor, CPA ( $\mathrm{n}=187$ cells). Similar increases in $(\mathrm{Ca} 2+)_{\mathrm{i}}$ occurred in WT FLS with and without extracellular $\mathrm{Ca}^{2+}$ in the bath (Figure 1D). On the other hand, pretreatment using CPA completely abolished the increases in $(\mathrm{Ca} 2+)_{i}$ produced by acidic $\mathrm{pH}$ (Figure $1 \mathrm{~B})$. Thus, the $(\mathrm{Ca} 2+)_{\mathrm{i}}$ increases in response to decreases in $\mathrm{pH}$ through ASICs occur by release from $(\mathrm{Ca} 2+)_{\mathrm{i}}$ stores.

To confirm that human FLS also respond to acidic $\mathrm{pH}$ in an ASIC-dependent manner, we examined the $(\mathrm{Ca} 2+)_{\mathrm{i}}$ intensities of RA FLS after treatment with $\mathrm{pH} 6.0$ with and without the non-selective ASIC blocker amiloride $(100 \mu \mathrm{M} \mathrm{n}=368$ cells; $250 \mu \mathrm{M} \mathrm{n}=322$ cells; $500 \mu \mathrm{M}$ $\mathrm{n}=304$ cells; controls, $\mathrm{n}=326$ cells). $\mathrm{pH} 6.0$ significantly increased $(\mathrm{Ca} 2+)_{\mathrm{i}}$ intensity in RA FLS (Figure 1E). Pre-treatment of the FLS with amiloride reduced this increase in $(\mathrm{Ca} 2+)_{\mathrm{i}}$ in a dose-dependent manner (Figure $1 \mathrm{C}$ ). A significant reduction in the amplitude of $\mathrm{pH}$ 6.0-induced $(\mathrm{Ca} 2+)_{\mathrm{i}}$ response occurred with $500 \mu \mathrm{M}$ amiloride $(P<0.05)$. Thus, ASICs mediate $(\mathrm{Ca} 2+)_{\mathrm{i}}$ increases induced by acidic $\mathrm{pH}$.

\section{Acidic $\mathrm{pH}$ decreases $\mathrm{p}$-ERK protein expression in FLS}

MAPKs play a significant role in mediating the inflammatory response by synoviocytes [16-20]. Therefore, we tested if MAPKs were modulated by acidic $\mathrm{pH}$ using western blot analysis. WT FLS were incubated in $\mathrm{pH}$ 6.0, and compared to $\mathrm{pH} 7.4$, (WT, $\mathrm{n}=9$ preparations/condition). Unexpectedly, p-ERK protein expression significantly decreased 15 minutes after exposure to $\mathrm{pH} 6$ in WT FLS when compared to the response at $\mathrm{pH} 7.4(P<0.05)$ (Figure $2 \mathrm{~A}$ and $\mathrm{B})$. No changes were observed in total ERK, or in p-JNK, JNK, p-p38, or p-38 (Figure 2A and B).

We then examined the contribution of ASICs to the acid-induced decrease in $\mathrm{p}$-ERK using ASIC3-/- $(\mathrm{n}=9$ / condition) and ASIC1-/- FLS ( $\mathrm{n}=9 /$ condition). The decrease in p-ERK expression induced by $\mathrm{pH} 6.0$ did not occur in ASIC3-/- FLS and was significantly greater than WT FLS treated with pH $6.0(P<0.05)$ (Figure $2 \mathrm{C})$. On the other hand, $\mathrm{p}$-ERK expression significantly decreased in ASIC1-/- FLS (Figure 2D). This decrease was similar to that observed in WT FLS treated with pH $6.0(P>0.05)$. Thus, the decreases in p-ERK induced by acidic $\mathrm{pH}$ require ASIC3, but not ASIC1. 

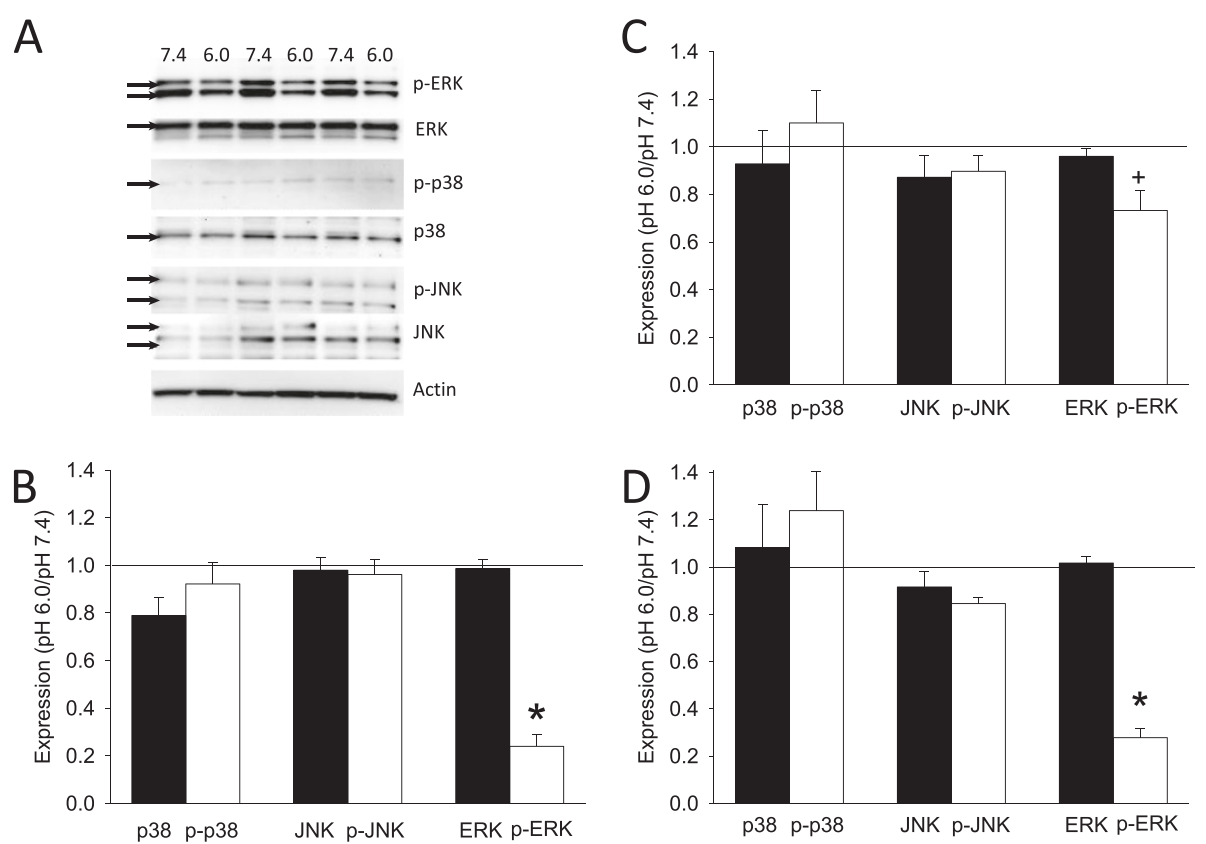

Figure 2 Western blot analysis determines the responses of mitogen-activated protein kinases (MAPKs) after incubation in $\mathrm{pH} 6.0$ or 7.4 in wild-type (WT), acid-sensing ion channel (ASIC3)-/- and ASIC1-/- fibroblast-like synoviocytes (FLS). (A) Representative western blots for extracellular signal-regulated kinase (ERK), p-ERK, p-p38, p-38, c-Jun N-terminal kinase (JNK), p-JNK and actin treated with pH 7.4 or pH 6.0. Blots were always run with pH 7.4 or pH 6.0 simultaneously. Notice the decreases in p-ERK with pH 6.0 when compared to pH 7.4. The bands that were quantified for each protein are highlighted with an arrow and are previously described by us [31]. (B) WT FLS: density of the individual bands was taken using Image J software and pH 6.0 was normalized to $\mathrm{pH} 7.4 ; \mathrm{pH} 6.0$ and pH 7.4 were always run simultaneously on the same blots to facilitate comparison between groups. Expression values of 1.0 represent no change, $<1.0$ represent a decrease in expression, and $>1.0$ represent an increase in expression. p-ERK protein expression significantly decreased after exposure to $\mathrm{pH} 6.0$ in WT FLS when compared to the response at pH $7.4(* P<0.05)$. (C) ASIC3-/- FLS: p-ERK protein expression was significantly greater 15 minutes after exposure to pH 6.0 in AS/C3-/- FLS when compared to WT FLS $\left({ }^{+} P<0.05\right)$. (D) ASIC1 - - FLS: p-ERK protein expression significantly decreased after exposure to pH 6 in ASIC1-/- FLS when compared to the response at $\mathrm{pH} 7.4\left({ }^{*} P<0.05\right)$, and was similar to the decreased expression observed in WT FLS.

\section{Role of $(\mathrm{Ca} 2+)_{i}$ in regulation of $\mathrm{p}$-ERK by acidic $\mathrm{pH}$}

As acidic $\mathrm{pH}$ increases $(\mathrm{Ca} 2+)_{\mathrm{i}}$ and decreases $\mathrm{p}$-ERK, we tested if blockade of $(\mathrm{Ca} 2+)_{\mathrm{i}}$ stores prevented the decrease in $\mathrm{p}$-ERK expression in WT FLS $(n=9$ preparations/condition). Pretreatment of FLS with CPA $(30 \mu \mathrm{M})$ prior to and during application of $\mathrm{pH} 6.0$ prevented the decrease in p-ERK in WT FLS (Figure 3A) $(P<0.05)$. There were no changes in ERK expression with CPA treatment. As protein phosphatase 2A (PP2A) can modulate ERK activity [27] and is activated by increases in $(\mathrm{Ca} 2+)_{\mathrm{i}}$, we then determined if PP2A blockade prevents the acidic $\mathrm{pH}$-induced decreases in $\mathrm{p}$-ERK. Inhibition of PP2A with fostriecin (FOS) (100 and 1,000 nM) dose-dependently prevented the decrease in p-ERK in WT FLS treated with $\mathrm{pH} 6.0$ (Figure 3B). A significant difference from those treated with $1,000 \mathrm{nM}$ FOS occurred when compared to control FLS not treated with FOS $(P<0.05)$.

Effects of the IL-1 $\beta$ on $\mathrm{pH}$-induced changes in FLS Previous studies show an upregulation of ASICs after inflammation in sensory neurons $[4,32,33]$; however, whether this upregulation occurs in other cells like FLS is unknown. To mimic the inflammatory conditions observed in vivo, we incubated FLS with the inflammatory cytokine IL-1 $\beta$ and examined expression of ASIC3 and ASIC1 mRNA using qPCR ( $\mathrm{n}=4$ preparations/group). There was a significant increase in expression of ASIC3 mRNA in FLS treated with IL-1 $\beta$ when compared to control FLS $(P<0.05)$. In contrast, there was a simultaneous decrease in expression of ASIC1 in WT FLS treated with IL-1 $\beta$ (Figure 4A) $(P<0.05)$. Thus, IL-1 $\beta$ significantly increased expression of ASIC3 in FLS.

To determine whether there was enhanced $(\mathrm{Ca} 2+)_{\mathrm{i}}$ in WT FLS sensitized by IL-1 $\beta$ we incubated FLS in IL-1 $\beta$ followed by exposure to $\mathrm{pH} 6.0$ ( $\mathrm{n}=112$ cells); all responses were normalized to responses to $\mathrm{pH} 7.4$ in the same cells. FLS exposed to the inflammatory mediator IL-1 $\beta$ demonstrated a significantly greater increase in $(\mathrm{Ca} 2+)_{\mathrm{i}}$ intensity to $\mathrm{pH} 6.0$ when compared to cells not treated with IL-1 $\beta$ (Figure $4 \mathrm{~B})(P<0.05)$. Thus, IL-1 $\beta$ enhanced the acid-induced increase in $(\mathrm{Ca} 2+)_{\mathrm{i}}$.

To determine whether acid-induced decreases in p-ERK are modified in cells sensitized by IL-1 $\beta$, we 


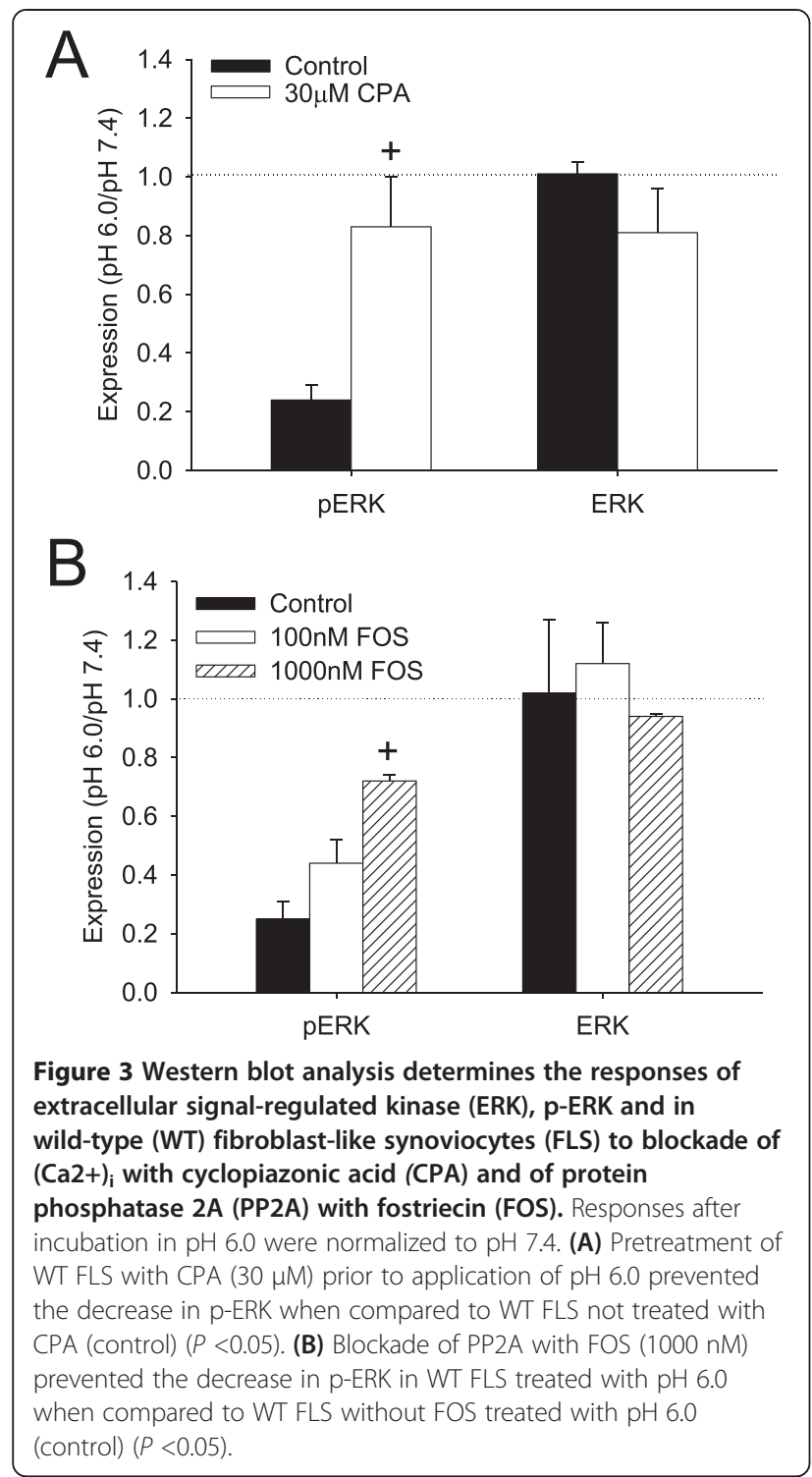

examined the effects of $\mathrm{pH} 6.0$ on p-ERK protein in WT FLS treated with IL-1 $\beta$ ( $\mathrm{n}=9$ preparations/condition). p-ERK expression in response to $\mathrm{pH} 6.0$ was significantly higher in WT FLS treated with IL-1 $\beta$, when compared to that observed in WT FLS without IL-1 $\beta$ (Figure 4C) $(P<0.05)$. The role of ASICs in the p-ERK changes was then explored using ASIC1//- and ASC3-/- FLS. Interestingly, a significant decrease in p-ERK in response to $\mathrm{pH} 6.0$ occurred after pre-treatment with IL-1 $\beta$ in both ASIC1-/ $(0.16 \pm 0.02, \mathrm{n}=9)$ FLS and ASIC3-/ $(0.26 \pm$ $0.05, \mathrm{n}=9)$ FLS $(P<0.05)$. No changes in ERK (Figure $4 C)$, JNK, p-JNK, p38, or p-p38 (data not shown) were observed in WT, ASIC3-/- or ASIC1-/- FLS treated with IL-1 $\beta$ and $\mathrm{pH}$ 6.0. Thus, the enhanced p-ERK expression observed in cells sensitized by IL-1 $\beta$ was mediated by ASIC1 and ASIC3.

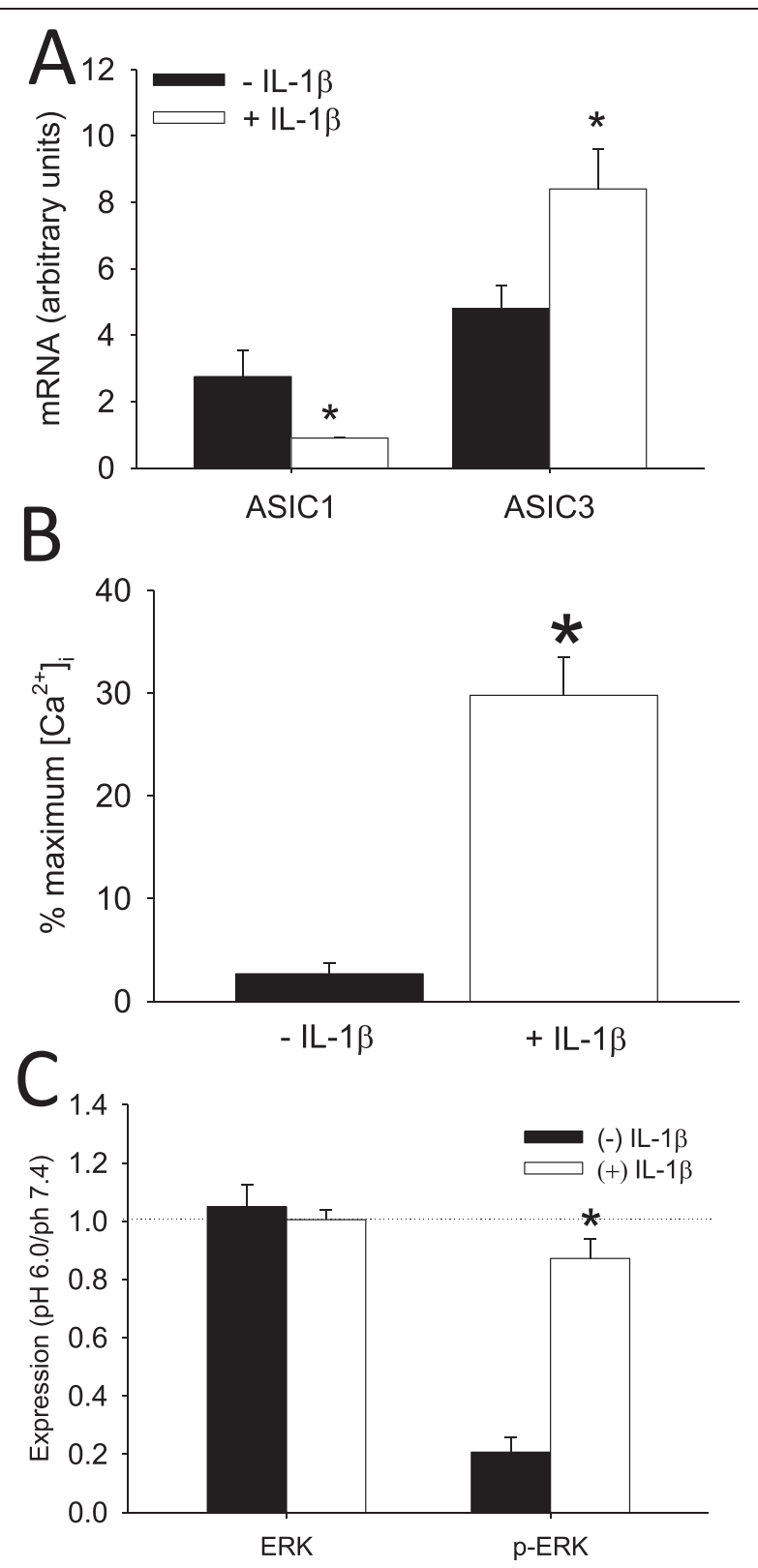

Figure 4 Effects of the inflammatory mediator IL-1 $\beta$ on acidinduced changes in wild-type (WT) fibroblast-like synoviocytes (FLS). (A) Real-time PCR of WT FLS determined the expression of acid-sensing ion channel (ASIC) 1 and ASIC3 after incubation with or without IL-1 $\beta$ at $\mathrm{pH}$ 7.4. There was a significant increase in expression of ASIC3 mRNA and a decrease in expression of ASIC1 mRNA in the group treated with IL-1 $\beta$ when compared to WT FLS not treated with IL-1 $\beta(P<0.05)$. (B) $\mathrm{Ca}^{2+}$ imaging determined $(\mathrm{Ca} 2+)_{\mathrm{i}}$ in WT FLS treated with IL-1 $\beta$ followed by exposure to $\mathrm{pH} 6.0$ and normalized to responses at $\mathrm{pH}$ 7.4. WT FLS incubated with IL-1 $\beta$ showed greater increases in (Ca2+), intensity when compared to WT FLS not treated with IL-1 $\beta(P<0.05)$. (C) Western blot analysis determined the acid-induced responses of extracellular signal-regulated kinase (ERK) and $p$-ERK in WT FLS treated with IL-1 $\beta$. After exposure to $\mathrm{pH}$ 6.0, p-ERK expression was significantly higher in WT FLS with IL-1 $\beta$ when compared to that in WT FLS without IL-1 $\beta(P<0.05)$. 
Regulation of FLS gene expression by acidic pH in FLS As our prior study in ASIC3-/- mice showed increases in IL-6, MMP-3 and MMP-13 gene expression in the ankle joint of arthritic mice when compared to WT mice [1], we tested whether acidic $\mathrm{pH}$ and ASIC3 modulate gene expression of these inflammatory mediators in FLS. In WT FLS treated with IL-1 $\beta$, there was a significant increase in mRNA expression for IL-6, MMP-3 and MMP-13 compared to WT FLS without IL-1 $\beta$ treatment. FLS treated with $\mathrm{pH} 6.0$ showed no difference from those treated with $\mathrm{pH} 7.4$, with or without IL-1 $\beta$. ASIC3-/- FLS showed similar increases in mRNA expression of IL-6, MMP-3 and MMP-13 after exposure to IL-1 $\beta$ and were not significantly different from WT FLS (Table 1). Thus, acidic $\mathrm{pH}$ and ASIC3 do not modulate the enhanced expression of IL-6, MMP-3 and MMP-13 induced by IL- $1 \beta$.

\section{Regulation of apoptosis by acidic $\mathrm{pH}$}

We previously showed that $\mathrm{pH} 6.0$ in combination with IL-1 $\beta$ enhanced synoviocyte cell death in FLS from WT mice when compared to IL-1 $\beta$ alone, $\mathrm{pH} 6.0$ alone, or $\mathrm{pH}$ 7.4, and this enhanced cell death depended on ASIC3 [14]. As increases in $(\mathrm{Ca} 2+)_{i}$ can induce cell death, and ASIC3 mediates the acid-induced increases in $(\mathrm{Ca} 2+)_{\mathrm{i}}$, we tested whether the acid-induced cell death depends on $(\mathrm{Ca} 2+)_{\mathrm{i}}$ in WT FLS. Representative images in Figure 5 show that cell death increased in WT FLS exposed to $\mathrm{pH} 6.0$ and IL-1 $\beta$ when compared to those exposed to $\mathrm{pH} 7.4$ with and or without IL-1 $\beta$. After exposure of WT FLS to IL-1 $\beta$ and $\mathrm{pH}$ 6.0, there were significantly fewer dead cells in the group incubated with BAPTA-AM to chelate $(\mathrm{Ca} 2+)_{\mathrm{i}}$ when compared to vehicle (Figure 5C,D,G). No changes in cell death occurred in FLS treated with $\mathrm{pH} 7.4$ with or without IL-1 $\beta$ (Figure 5A,B,G,H).

As we showed that acid-induced decreases in p-ERK are modulated by increases in $(\mathrm{Ca} 2+)_{\mathrm{i}}$, and prior studies show that inhibiting ERK attenuates cell death [25], we tested whether blockade of ERK would prevent the acidinduced cell death. FLS treated with PD98059 displayed significantly less death in response to IL- $1 \beta$ and $\mathrm{pH} 6.0$ when compared to WT FLS controls (pH $6.0+\mathrm{IL}-1 \beta$ ) (Figure 5E,F,H). No changes in cell death occurred in FLS treated with $\mathrm{pH} 7.4$ and IL-1 $\beta$ with or without PD9805 (Figure 5C). Thus, $(\mathrm{Ca} 2+)_{\mathrm{i}}$ and ERK modulate the enhanced cell death that occurs in response to acidic-pH under inflammatory conditions.

\section{Discussion}

The current study demonstrated a unique role for ASIC3 in FLS in modulating $(\mathrm{Ca} 2+)_{\text {i }}$, phosphorylation of the MAP kinase ERK, and cell death induced by acidic $\mathrm{pH}$. Specifically, we showed that activation of ASIC3 by acidic-pH increases $(\mathrm{Ca} 2+)_{\mathrm{i}}$ in FLS, which subsequently reduces phosphorylation of ERK and this reduced p-ERK is prevented by blockade of PP2A. After sensitization of FLS with IL-1 $\beta$, which mimics inflammatory synovitis: 1 ) acidic $\mathrm{pH}$ further enhances $(\mathrm{Ca} 2+)_{\mathrm{i}}$; 2$)$ acid-induced decreases in p-ERK are abolished, and 3) acidic $\mathrm{pH}$ induces apoptosis. The cell death that occurs in IL-1 $\beta$-treated FLS exposed to acidic $\mathrm{pH}$ is blocked by chelation of $(\mathrm{Ca} 2+)_{\mathrm{i}}$, inhibition of ERK, and does not occur in ASIC3-/- FLS [1]. Further, there is enhanced inflammation and joint degradation in ASIC3-/- mice with passive collagen-induced arthritis (CAIA) [1]. Taken together these data support a protective role of ASIC3 under inflammatory conditions - activation of ASIC3 would cause cell death and limit synovitis.

\section{Role of ASICs in $(\mathrm{Ca} 2+)_{i}$ increases in FLS}

Our data agree with prior studies showing that acidic $\mathrm{pH}$ increases $(\mathrm{Ca} 2+)_{\mathrm{i}}[1,9,34,35]$. In agreement with our prior study [9], ASIC3 mediates these increases. We further show that genetic deletion of ASIC1 also reduced the $(\mathrm{Ca} 2+)_{\mathrm{i}}$ produced by acidic $\mathrm{pH}$. Interestingly, previous studies show increases within the same $\mathrm{pH}$ range as the present study, pH 5.5 or with $\mathrm{pH} 6.8$; however direct

Table 1 Real-time PCR determines the gene expression of cytokines in WT FLS and ASIC3-/- FLS after incubation in pH 6.0 or 7.4 with or without IL-1 $\beta$

\begin{tabular}{|c|c|c|c|c|c|}
\hline \multirow[t]{2}{*}{ Cytokine } & \multirow{2}{*}{$\begin{array}{l}\mathrm{Il}-1 \mathrm{~b} \\
\text { treatment }\end{array}$} & \multicolumn{2}{|l|}{$\mathrm{pH} 7.4$} & \multicolumn{2}{|l|}{$\mathrm{pH} 6.0$} \\
\hline & & WT & ASIC3-/- & WT & ASIC3-/- \\
\hline \multirow[t]{2}{*}{ IL-6 } & $(-)$ & $0.0018 \pm 0.0009$ & $0.0007 \pm 0.0002$ & $0.0037 \pm 0.0028$ & $0.001 \pm 0.0004$ \\
\hline & $(+)$ & $0.0886 \pm 0.0218$ & $0.1136 \pm 0.013$ & $0.1488 \pm 0.0503$ & $0.1829 \pm 0.0411$ \\
\hline \multirow[t]{2}{*}{ MMP-3 } & $(-)$ & $0.0307 \pm 0.0042$ & $0.0180 \pm 0.0060$ & $0.0373 \pm 0.0072$ & $0.0207 \pm 0.0097$ \\
\hline & $(+)$ & $1.7975 \pm 0.7027$ & $1.7750 \pm 0.712$ & $1.81 \pm 0.7002$ & $1.8055 \pm 0.6042$ \\
\hline \multirow[t]{2}{*}{ MMP-13 } & $(-)$ & $0.0642 \pm 0.0062$ & $0.0677 \pm 0.0308$ & $0.0761 \pm 0.006$ & $0.0879 \pm 0.0526$ \\
\hline & $(+)$ & $1.5977 \pm 0.4506$ & $1.5066 \pm 0.5933$ & $1.8362 \pm 0.5362$ & $1.5015 \pm 0.5819$ \\
\hline
\end{tabular}

mRNA expression of IL-6, metalloproteinase (MMP)-3 and MMP-13 all significantly increased in wild-type (WT) fibroblast-like synoviocytes (FLS) and acid-sensing ion channel (ASIC3)-/- FLS treated with IL-1 $\beta$ when compared to FLS without IL-1 $\beta$. There were no differences between WT FLS treated with pH 6.0 and those treated $\mathrm{pH} 7.4$, and there was no difference between WT FLS and ASIC3-/- FLS. Results are presented as mean \pm standard error of the mean. 


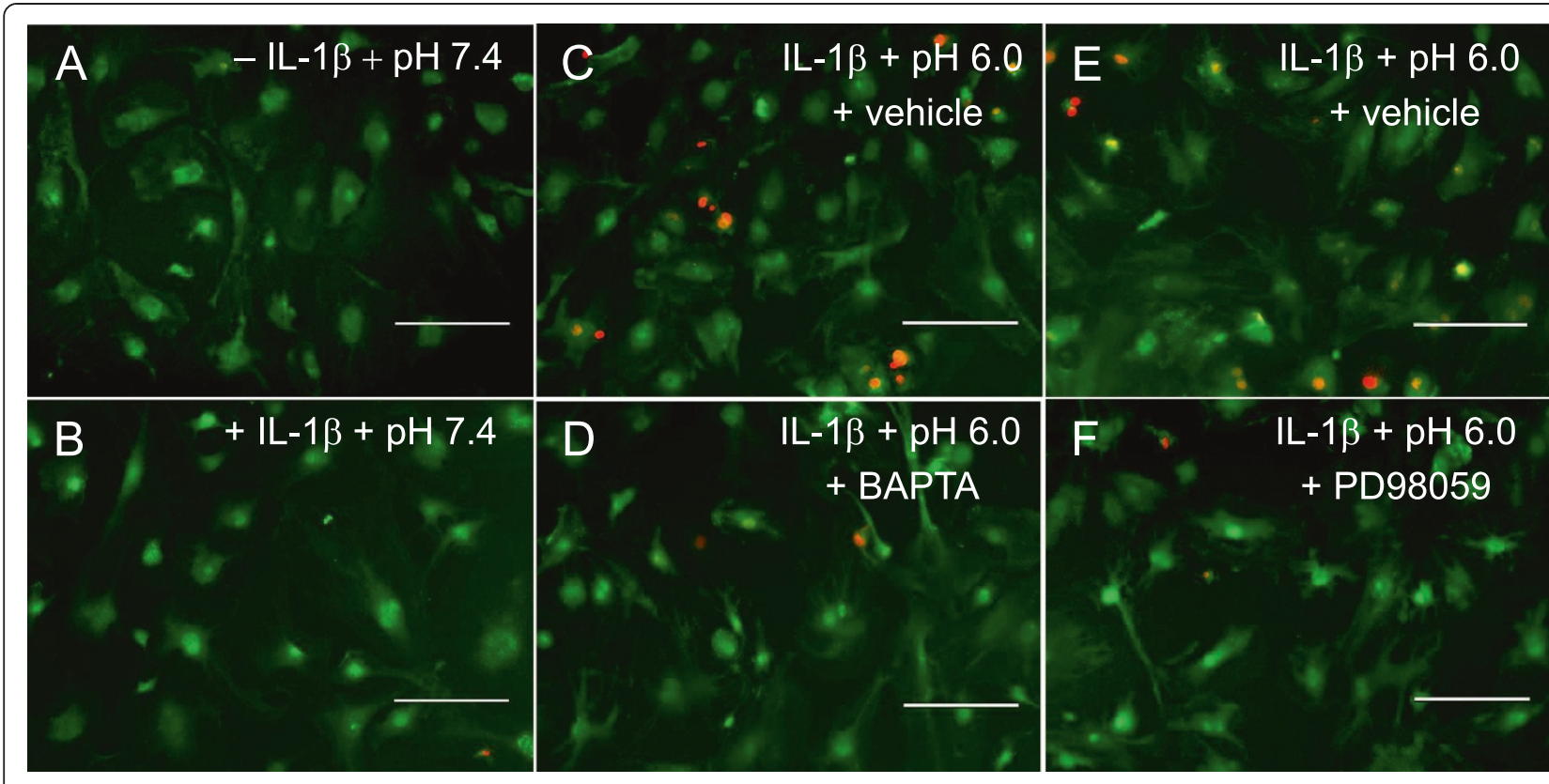

G

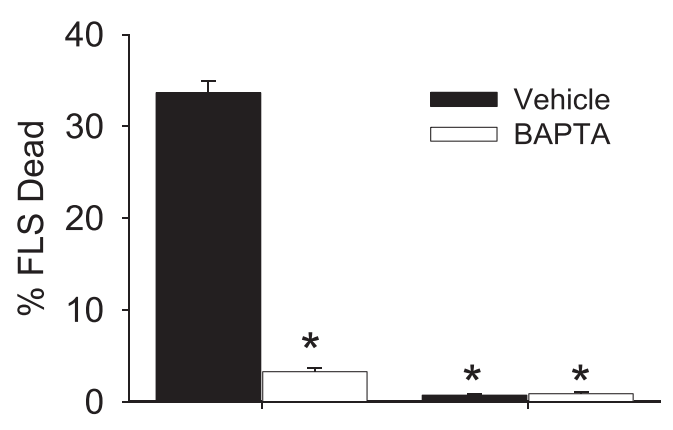

$\mathrm{pH} 6.0$

$\mathrm{pH} 7.4$
$\mathrm{H}$

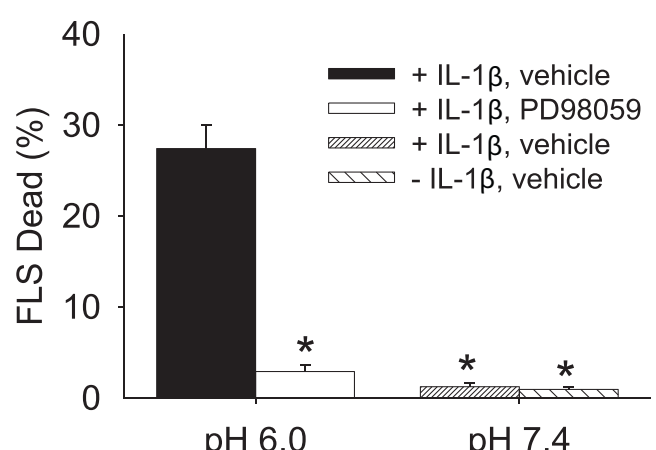

$\mathrm{pH} 6.0$

Figure 5 Live/Dead assays determined calcium dependency and extracellular signal-regulated kinase (ERK) contribution to cell death induced by $\mathrm{pH} 6.0$ with IL-1 $\beta$. The number of dead fibroblast-like synoviocytes (FLS) and the number of live FLS were counted to obtain the percent dead. (A-F) Representative images from FLS stained using a Live/Dead Viability/Cytotoxicity kit. Live cells were stained with calcein AM (green), dead cells were stained with ethidium homodimer (red). (A and B) Show images of FLS treated by pH 7.4 without or with IL-1 3 , respectively. (C and $\mathbf{D}$ ) Show images of FLS treated by pH 6.0 and IL-1 $\beta$ without or with intracellular calcium chelating agent (BAPTA, $1 \mu \mathrm{M}$ ), respectively; (E and F) show images of FLS treated by pH 6.0 and IL-1 $\beta$ without or with inhibitor of ERK (PD98059,10 $\mu \mathrm{M}$ ), respectively. (G) Quantitative analysis shows approximately $30 \%$ dead FLS after treatment with pH 6.0 and IL-1 $\beta$, which was significantly greater than FLS treated with $\mathrm{pH} 6.0$ and IL-1 $\beta$ with BAPTA, and $\mathrm{pH} 7.4$ and IL-1 $\beta$ with and without BAPTA ( ${ }^{*} P<0.01$ ). (H) Quantitative analysis shows approximately $30 \%$ dead FLS after treatment with pH 6.0 and IL-1 $\beta$, which was significantly greater than FLS treated with pH 6.0 and IL-1 $\beta$ with PD98059 (10 $\mu$ M), and FLS with or without IL-1 $\beta$ and $\mathrm{pH} 7.4\left({ }^{*} P<0.001\right)$. Data are mean \pm standard error of the mean.

comparison of $(\mathrm{Ca} 2+)_{\mathrm{i}}$ responses between differing acidic $\mathrm{pH}$ was not previously examined, and these studies were done from FLS taken from animals with CAIA [35,36]. In the current study we did not eliminate all $(\mathrm{Ca} 2+)_{\mathrm{i}}$ increases in FLS from ASIC3-/- or from ASIC1-/-. As ASICs form heteromers [5,37], TRPV1 can respond to acidic $\mathrm{pH}$ [38,39], and a G-proton-sensing acid channel was previously identified in FLS [40], it is likely that removal of any one channel would not eliminate the acid-response. The overall abundance of TRPV1 (transient receptor potential cation channel vanilloid 1) is relatively low in comparison to ASIC3 in FLS from WT mice [9] suggesting a larger contribution of proton response occurs for ASIC. Interestingly, capsaicin-evoked increases in $(\mathrm{Ca} 2+)_{\mathrm{i}}$ were actually reduced at $\mathrm{pH} 6.8$ suggesting another channel or process inhibits the TRPV1 channel. Since each ion channel might have different intracellular targets, their response to acid could be unique. Thus, ion channels located on FLS can control levels of $(\mathrm{Ca} 2+)_{\mathrm{i}}$ and are activated and modulated by decreases in $\mathrm{pH}$. 


\section{Role of ASICs in modulation of $p$-ERK}

Decreased ERK phosphorylation in response to acidic $\mathrm{pH}$ in WT FLS was surprising, as MAPKs enhance inflammatory cytokine expression in FLS [16-20]. Synoviocytes are key players in the production of inflammatory mediators (for example, IL-6, TNF, MMP), which subsequently enhance the inflammatory process and joint damage [13-17]. Prior studies showed that increased $(\mathrm{Ca} 2+)_{\mathrm{i}}$ enhanced expression of the catalytic subunit of PP2A which decreased ERK phosphorylation [27]. We confirmed the role of calcium and PP2A by showing that the decrease in p-ERK is reduced by blockade of PP2A and $(\mathrm{Ca} 2+)_{\mathrm{i}}$. It is possible that the changes in p-ERK that occur by blockade of PP2A are the result of a direct action of PP2A on p-ERK changes or a parallel pathway that results in increased ERK.

\section{Effects of acidic pH under inflammatory conditions}

The current study shows differences in response to acidic $\mathrm{pH}$ in FLS treated with IL-1 $\beta$, including enhanced $(\mathrm{Ca} 2+)_{\mathrm{i}}$, no changes in $\mathrm{p}$-ERK, and cell death. Exposure to inflammatory mediators such as IL- $1 \beta$ can be used to mimic the inflammatory condition. We recognize there are a number of other key mediators present in arthritic joints, for example, TNF and IL-6, and future experiments should examine their effects on ASICs.

Our prior study in ASIC3-/- mice with CAIA showed enhanced swelling as well as enhanced IL-6, MMP-3 and MMP-13 expression in the joint tissue [1] suggesting that ASIC3 might reduce gene expression of these inflammatory mediators. Although IL- $1 \beta$ increased expression of IL-6, MMP-3 and MMP-13 in WT FLS, these changes were similar after application of acidic $\mathrm{pH}$ and in ASIC3-/FLS. Thus, we conclude that the enhanced expression of inflammatory mediators in ASIC3-/- mice results from excess synoviocyte proliferation that would normally be prevented in WT mice by the activation of ASIC3 on FLS in the acidic environment of an inflamed joint.

Synovial intimal lining hyperplasia is a hallmark of RA and synoviocytes release inflammatory cytokines and MMPs contributing to the inflammation and joint destruction $[20,41]$. Increasing synoviocyte cell death during synovitis might be a mechanism to control inflammatory joint disease progression. For example, a prior study that expressed human calcineurin binding protein 1 in synoviocytes of mice with CAIA showed enhanced cell death and reduced cytokine and MMP expression [42]. In contrast the endogenous substance vascular endothelial growth factor (VEGF) protects against synoviocyte cell death, is increased in synovial fluid from individuals with RA [43], and blockade of VEGF reduces disease severity in mice with CAIA and enhances cell death in cultured synoviocytes [44]. Thus, we propose that ASIC3 plays a role in limiting synovitis by inducing cell death under conditions of inflammation where the $\mathrm{pH}$ of the joint is reduced; this could be a normal healthy response to joint inflammation.

Our prior work shows that ASIC3-/- mice have enhanced inflammation and joint degradation, and sensitizing FLS with the inflammatory mediator IL-1 $\beta$ results in cell death to $\mathrm{pH} 6$ that requires ASIC3 [1]. The current study showed that this IL-1 $\beta$-acid-induced cell death of FLS requires $(\mathrm{Ca} 2+)_{\mathrm{i}}$ increases and activation of ERK. This

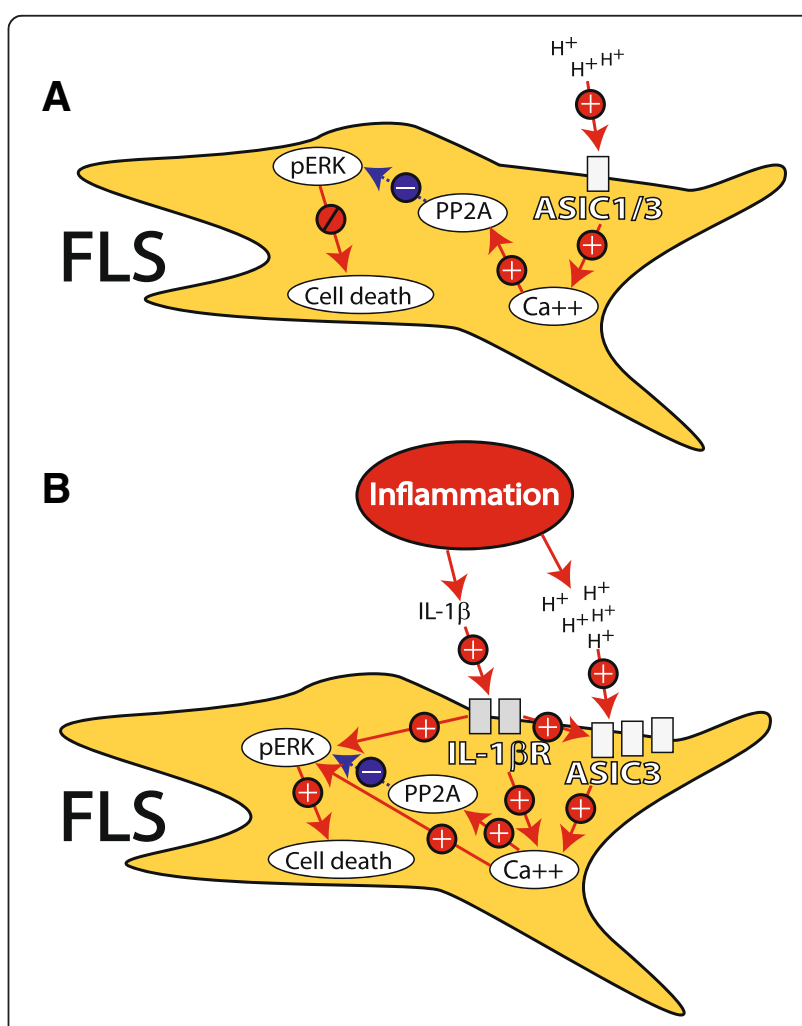

Figure 6 A schematic of the role of acid-sensing ion channel (ASIC) 1 and ASIC3 involved in synoviocyte function under normal and inflammatory conditions. (A) This diagram shows fibroblast-like synoviocytes (FLS) under normal non inflamed conditions. Extracellular protons $\left(\mathrm{H}^{+}\right.$, acidic $\left.\mathrm{pH}\right)$ activate the ASIC3 and ASIC1 that increase calcium release from intracellular stores. The increases in intracellular calcium through ASIC3 activate protein phosphatase 2A (PP2A) which subsequently dephosphorylates extracellular signal-regulated kinase (ERK). This reduction in phosphorylation of ERK counteracts the increases in intracellular calcium so that there is no cell death of FLS. (B) Under inflammatory conditions, FLS are exposed to inflammatory mediators, such as IL-1 $\beta$ as well as an acidic environment. The combination of these two factors results an enhanced response and cell death. IL-1 $\beta$ increases expression of ASIC 3 and decreases expression of ASIC1 results in ion channels with a greater proportion of ASIC3 on FLS to sense the increased protons from the acidic environment. Activation of ASIC3 by protons would then result in enhanced calcium release intracellularly. IL-1 $\beta$ by itself can modulate calcium and can enhance phosphorylation of ERK. This enhanced intracellular calcium by activation of ASIC3 and IL-1 $\beta$, along with enhanced phosphorylation of $\mathrm{p}$-ERK by activation of IL-1 $\beta$ receptor activation shifts the balance of calcium and p-ERK to favor cell death. Thus, under inflammatory conditions, decreases in $\mathrm{pH}$ activate ASIC3 to produce cell death. 
agrees with prior studies showing that ERK activation can cause cell death in a variety of cell types including neurons, cancer, chondrocytes and macrophages [23-26] - we now show that ERK plays a role in cell death of synoviocytes. In contrast to our study, RA FLS stimulated with VEGF, which protects against cell death, increases p-ERK and this increase in p-ERK is blocked by inhibition of VEGF [45]. ERK activation in synoviocytes could be dependent on the state of the cell, the location of ERK within a cell compartment, the cell surface and intracellular pathways that are connected to ERK, or the ERK subtype activated.

\section{Conclusions}

Inflammation, joint damage, and pain are critical components of RA. The current study suggests that activation of ASIC3 on FLS can modulate inflammation by enhancing synoviocyte cell death and limit synovitis. Thus ASIC3 could be a therapeutic target to control disease progression. In contrast, our previously published work consistently shows that ASIC3 plays a role in the transmission of nociceptive (painful) information in animal models of musculoskeletal pain where there are reduced pain behaviors in ASIC3-/- mice or downregulation of ASIC3 in peripheral neurons [1-3,6-8]. Thus, ASIC3 located on nociceptors innervating inflamed tissue appears to produce pain-behaviors while simultaneously through its location on synoviocytes reduces inflammation by causing synoviocyte cell death. Future studies should determine if alterations in ASIC3, activation and blockade, have differential effects in WT animals with inflammatory arthritis.

In normal resting FLS, decreases in $\mathrm{pH}$ activate ASIC3 to increase $(\mathrm{Ca} 2+)_{\mathrm{i}}$ activating PP2A, which dephosphorylates ERK and there is no cell death (Figure 6). Decreases in $\mathrm{pH}$ also activate ASIC1 to increase $(\mathrm{Ca} 2+)_{\mathrm{i}}$. In synovitis, inflammatory mediators are released that can activate intracellular pathways to increase expression of ASIC3, decrease expression of ASIC1, increase $(\mathrm{Ca} 2+)_{\mathrm{i}}$, and increase phosphorylation of ERK. The consequence of this is an amplified response to acidic $\mathrm{pH}$ to result in cell death. Thus, decreases in $\mathrm{pH}$ under inflammatory conditions play a protective role by activating ASIC3 to limit synovitis and could be a potential new therapeutic target.

\footnotetext{
Abbreviations

ANOVA: analysis of variance; ASIC: acid sensing ion channel; CAIA: collageninduced arthritis; CPA: cyclopiazonic acid; DMEM: Dulbecco's modified Eagle's medium; ERK: extracellular signal-regulated kinase; FBS: fetal bovine serum; FLS: fibroblast-like synoviocyte; FOS: fostriecin; IL: interleukin; JNK: c-Jun N-terminal kinase; MAPK: mitogen-activated protein kinase; MMP: metalloproteinase; OGB-1: Oregon green BAPTA-1-AM; PP2A: protein phosphatase 2A; qPCR: quantitative real time polymerase chain reaction; RA: rheumatoid arthritis; SERCA: sarco-endoplasmic reticulum $\mathrm{Ca}^{2+}$-ATPase; TNF: tumor necrosis factor; VEGF: vascular endothelial growth factor; WT: wild-type.
}

\section{Competing interests}

The authors have no competing financial or non-financial interests directly related to this manuscript.

\section{Authors' contributions}

WG carried out cell death experiments, wrote an initial draft of the manuscript, and read and revised the manuscript. SK carried out the calcium imaging, was involved in design of all studies, trained WG in cell-death experiments, wrote some methods for the manuscript, and read and revised the manuscript. YU was involved in experimental design for the calcium imaging studies, and read and edited the manuscript. RW was involved in experimental design of the experiments, and developed and trained technical support on western blot analysis. DB carried out the qPCR experiments, was involved in experimental design, and edited the manuscript. GF conceived of the ideas, was involved in experimental design and edited the manuscript. KS conceived of the ideas, was involved in experimental design of all experiments, performed statistical analysis, coordinated the experiments, and wrote and revised the final draft of the manuscript. All authors read and approved the final version of the manuscript.

\section{Acknowledgements}

The authors wish to thank Jeanne Knecht and Lynn Rasmussen for excellent technical service. We also thank the Central Microscopy Research Facility at the University of lowa for technical help. Funding: NIH grants AR-053509 and AR-053509-S1 and S10 RR025439-01.

\section{Author details}

'Department of Anesthesiology, Fujian Medical University Union Hospital, Fuzhou City, Fujian, China. ${ }^{2}$ Department of Physical Therapy and Rehabilitation Science, Pain Research Program, University of lowa Carver College of Medicine, 500 Newton Road, 1-248 Medical Education Building, lowa City, IA 52242, USA. ${ }^{3}$ Department of Pharmacology, University of lowa Carver College of Medicine, lowa City, IA 52242, USA. ${ }^{4}$ Division of

Rheumatology, Allergy and Immunology, University of California San Diego School of Medicine, La Jolla, CA, USA.

Received: 4 December 2013 Accepted: 20 May 2014

Published: 12 June 2014

\section{References}

1. Sluka KA, Rasmussen LA, Edgar MM, O'Donnel JM, Walder RY, Kolker SJ, Boyle DL, Firestein GS: Acid sensing ion channel 3 deficiency increases inflammation but decreases pain behavior in arthritis. Arthritis Rheum 2013, 65:1194-1202.

2. Walder RY, Gautam M, Wilson SP, Benson CJ, Sluka KA: Selective Targeting of ASIC3 using miRNAs inhibits primary and secondary hyperalgesia following muscle inflammation. Pain 2011, 152:2348-2356.

3. Walder RY, Rasmussen LA, Rainier JD, Light AR, Wemmie JA, Sluka KA: ASIC1 and ASIC3 play different roles in the development of hyperalgesia after inflammatory muscle injury. J Pain 2010, 11:210-218.

4. Ikeuchi M, Kolker SJ, Sluka KA: Acid-sensing ion channel 3 expression in mouse knee joint afferents and effects of carrageenan-induced arthritis. J Pain 2009, 10:336-342.

5. Sluka KA, Winter OC, Wemmie JA: Acid-sensing ion channels: A new target for pain and CNS diseases. Curr Opin Drug Discov Devel 2009, 12:693-704.

6. Ikeuchi M, Kolker SJ, Burnes LA, Walder RY, Sluka KA: Role of ASIC3 in the primary and secondary hyperalgesia produced by joint inflammation in mice. Pain 2008, 137:662-669.

7. Sluka KA, Radhakrishnan R, Benson CJ, Eshcol JO, Price MP, Babinski K, Audette KM, Yeomans DC, Wilson SP: ASIC3 in muscle mediates mechanical, but not heat, hyperalgesia associated with muscle inflammation. Pain 2007, 129:102-112.

8. Sluka KA, Price MP, Breese NM, Stucky CL, Wemmie JA, Welsh MJ: Chronic hyperalgesia induced by repeated acid injections in muscle is abolished by the loss of ASIC3, but not ASIC1. Pain 2003, 106:229-239.

9. Kolker SJ, Walder RY, Usachev Y, Hillman J, Boyle DL, Firestein GS, Sluka KA: ASIC3 expressed in Type B synoviocytes and chondrocytes modulates hyaluronan expression and release. Ann Rheum Dis 2010, 69:903-909.

10. Goldie I, Nachemson A: Synovial pH in rheumatoid knee joints. II. The effect of local corticosteroid treatment. Acta Orthop Scand 1970, 41:354-362. 
11. Goldie I, Nachemson A: Synovial pH in rheumatoid knee-joints. I. The effect of synovectomy. Acta Orthop Scand 1969, 40:634-641.

12. Waldmann R, Champigny G, Lingueglia E, De Weille JR, Heurteaux C, Lazdunski M: H(+)-gated cation channels. Ann NY Acad Sci 1999, 868:67-76.

13. McNearney T, Baethge BA, Cao S, Alam R, Lisse JR, Westlund KN: Excitatory amino acids, TNF-alpha, and chemokine levels in synovial fluids of patients with active arthropathies. Clin Exp Immunol 2004, 137:621-627.

14. Houssiau FA, Devogelaer JP, Van DJ, de Deuxchaisnes CN, Van SJ: Interleukin-6 in synovial fluid and serum of patients with rheumatoid arthritis and other inflammatory arthritides. Arthritis Rheum 1988, 31:784-788.

15. Kaneko S, Satoh T, Chiba J, Ju C, Inoue K, Kagawa J: Interleukin-6 and interleukin-8 levels in serum and synovial fluid of patients with osteoarthritis. Cytokines Cell Mol Ther 2000, 6:71-79.

16. Sweeney SE, Firestein GS: Rheumatoid arthritis: regulation of synovial inflammation. Int J Biochem Cell Biol 2004, 36:372-378.

17. Inoue T, Boyle DL, Corr M, Hammaker D, Davis RJ, Flavell RA, Firestein GS: Mitogen-activated protein kinase kinase 3 is a pivotal pathway regulating p38 activation in inflammatory arthritis. Proc Natl Acad Sci U S A 2006, 103:5484-5489.

18. Han Z, Boyle DL, Chang L, Bennett B, Karin M, Yang L, Manning AM, Firestein GS: c-Jun N-terminal kinase is required for metalloproteinase expression and joint destruction in inflammatory arthritis. $J$ Clin Invest 2001, 108:73-81.

19. Han Z, Chang L, Yamanishi Y, Karin M, Firestein GS: Joint damage and inflammation in c-Jun $\mathrm{N}$-terminal kinase 2 knockout mice with passive murine collagen-induced arthritis. Arthritis Rheum 2002, 46:818-823.

20. Sweeney SE, Firestein GS: Signal transduction in rheumatoid arthritis. Curr Opin Rheumatol 2004, 16:231-237.

21. Han Z, Boyle DL, Aupperle KR, Bennett B, Manning AM, Firestein GS: Jun N-terminal kinase in rheumatoid arthritis. J Pharmacol Exp Ther 1999 291:124-130.

22. Cha HS, Boyle DL, Inoue T, Schoot R, Tak PP, Pine P, Firestein GS: A novel spleen tyrosine kinase inhibitor blocks c-Jun N-terminal kinase-mediated gene expression in synoviocytes. J Pharmacol Exp Ther 2006, 317:571-578.

23. Hayashi S, Nishiyama T, Miura Y, Fujishiro T, Kanzaki N, Hashimoto S, Matsumoto T, Kurosaka M, Kuroda R: DcR3 induces cell proliferation through MAPK signaling in chondrocytes of osteoarthritis. Osteoarthritis Cartilage 2011, 19:903-910.

24. Philpott $\mathrm{KL}$, Facci L: MAP kinase pathways in neuronal cell death. CNS Neurol Disord Drug Targets 2008, 7:83-97.

25. Asim M, Chaturvedi R, Hoge S, Lewis ND, Singh K, Barry DP, Algood HS, de Sablet T, Gobert AP, Wilson KT: Helicobacter pylori induces ERKdependent formation of a phospho-c-Fos c-Jun activator protein-1 complex that causes apoptosis in macrophages. J Biol Chem 2010, 285:20343-20357.

26. Hahm ER, Lee J, Singh SV: Role of mitogen-activated protein kinases and Mcl-1 in apoptosis induction by withaferin A in human breast cancer cells. Mol Carcinog 2013. doi:10.1002/mc.22050.

27. Liu WH, Chang LS: Caffeine induces matrix metalloproteinase-2 (MMP-2) and MMP-9 down-regulation in human leukemia U937 cells via Ca2 +/ROS-mediated suppression of ERK/c-fos pathway and activation of p38 MAPK/c-jun pathway. J Cell Physiol 2010, 224:775-785.

28. Price MP, Mcllwrath SL, Xie J, Cheng C, Qiao J, Tarr DE, Sluka KA, Brennan TJ, Lewin GR, Welsh MJ: The DRASIC Cation Channel contributes to the detection of cutaneous touch and acid stimuli in mice. Neuron 2001, 32:1071-1083.

29. Wemmie JA, Chen J, Askwith CC, Hruska-Hageman AM, Price MP, Nolan BC, Yoder PG, Lamani E, Hoshi T, Freeman JH Jr, Welsh MJ: The acid-activated ion channel ASIC contributes to synaptic plasticity, learning, and memory. Neuron 2002, 34:463-477.

30. Eshcol JO, Harding AM, Hattori T, Costa V, Welsh MJ, Benson CJ: Acidsensing ion channel 3 (ASIC3) cell surface expression is modulated by PSD-95 within lipid rafts. Am J Physiol Cell Physiol 2008, 295:C732-C739.

31. Boyle DL, Rosengren S, Bugbee W, Kavanaugh A, Firestein GS: Quantitative biomarker analysis of synovial gene expression by real-time PCR. Arthritis Res Ther 2003, 5:R352-R360.

32. Voilley N, de Weille J, Mamet J, Lazdunski M: Nonsteroid anti-inflammatory drugs inhibit both the activity and the inflammation-induced expression of acid-sensing ion channels in nociceptors. J Neurosci 2001, 21:8026-8033.
33. Mamet J, Baron A, Lazdunski M, Voilley N: Proinflammatory mediators, stimulators of sensory neuron excitability via the expression of acid-sensing ion channels. J Neurosci 2002, 22:10662-10670.

34. Kochukov MY, McNearney TA, Fu Y, Westlund KN: Thermosensitive TRP ion channels mediate cytosolic calcium response in human synoviocytes. Am J Physiol Cell Physiol 2006, 291:C424-C432.

35. Hu F, Sun WW, Zhao XT, Cui ZJ, Yang WX: TRPV1 mediates cell death in rat synovial fibroblasts through calcium entry-dependent ROS production and mitochondrial depolarization. Biochem Biophys Res Commun 2008, 369:989-993.

36. Hu F, Yang S, Zhao D, Zhu S, Wang Y, Li J: Moderate extracellular acidification inhibits capsaicin-induced cell death through regulating calcium mobilization, NF-kappaB translocation and ROS production in synoviocytes. Biochem Biophys Res Commun 2012, 424:196-200.

37. Waldmann $\mathrm{R}$, Lazdunski M: $\mathrm{H}(+)$-gated cation channels: neuronal acid sensors in the NaC/DEG family of ion channels. Curr Opin Neurobiol 1998, 8:418-424.

38. Caterina MJ, Leffler A, Tominaga M, Rosen TA, Levine JD, Julius D: The capsaicin receptor: a heat-activated ion channel in the pain pathway. Nature 1997, 389:816-824.

39. Tominaga M, Caterina MJ, Malmberg AB, Rosen TA, Gilbert H, Skinner K, Raumann BE, Basbaum Al, Julius D: The cloned capsaicin receptor integrates multiple pain-producing stimuli. Neuron 1998, 21:531-543.

40. Christensen BN, Kochukov M, McNearney TA, Taglialatela G, Westlund KN: Proton-sensing $\mathrm{G}$ protein-coupled receptor mobilizes calcium in human synovial cells. Am J Physiol Cell Physiol 2005, 289:C601-C608.

41. Christodoulou C, Choy EH: Joint inflammation and cytokine inhibition in rheumatoid arthritis. Clin Exp Med 2006, 6:13-19.

42. Yi JK, Kim HJ, Yu DH, Park SJ, Shin MJ, Yuh HS, Bae KB, Ji YR, Kim NR, Park SJ, Kim JY, Lee HS, Lee SG, Yoon du H, Hyun BH, Kim WU, Ryoo ZY: Regulation of inflammatory responses and fibroblast-like synoviocyte apoptosis by calcineurin-binding protein 1 in mice with collagen-induced arthritis. Arthritis Rheum 2012, 64:2191-2200.

43. Lee SS, Joo YS, Kim WU, Min DJ, Min JK, Park SH, Cho CS, Kim HY: Vascular endothelial growth factor levels in the serum and synovial fluid of patients with rheumatoid arthritis. Clin Exp Rheumatol 2001, 19:321-324.

44. Kong JS, Yoo SA, Kim JW, Yang SP, Chae CB, Tarallo V, De Falco S, Ryu SH, Cho CS, Kim WU: Anti-neuropilin-1 peptide inhibition of synoviocyte survival, angiogenesis, and experimental arthritis. Arthritis Rheum 2010, 62:179-190.

45. Kim WU, Kang SS, Yoo SA, Hong KH, Bae DG, Lee MS, Hong SW, Chae CB, Cho CS: Interaction of vascular endothelial growth factor 165 with neuropilin-1 protects rheumatoid synoviocytes from apoptotic death by regulating $\mathrm{BCl}-2$ expression and Bax translocation. J Immunol 2006, 177:5727-5735.

\section{doi:10.1186/ar4577}

Cite this article as: Gong et al:: Acid-sensing ion channel 3 decreases phosphorylation of extracellular signal-regulated kinases and induces synoviocyte cell death by increasing intracellular calcium. Arthritis Research \& Therapy 2014 16:R121.

\section{Submit your next manuscript to BioMed Central and take full advantage of:}

- Convenient online submission

- Thorough peer review

- No space constraints or color figure charges

- Immediate publication on acceptance

- Inclusion in PubMed, CAS, Scopus and Google Scholar

- Research which is freely available for redistribution 